\title{
The Process of Establishing Islamic Education at Wali Barokah Islamic Boarding School in Kediri, Indonesia
}

\author{
Anis Humaidi', Najihatul Fadhliyah ${ }^{2}$, Muawanah ${ }^{3}$, Nurul Hanani ${ }^{4}$, Muhammad Afif Amrulloh ${ }^{5}$, Dwi \\ Noviatul Zahra ${ }^{6}$, Mihmidaty Ya'cub ${ }^{7}$, \\ ${ }^{1}$ Institut Agama Islam Negeri Kediri, Indonesia \\ ${ }^{2}$ Institut Agama Islam Negeri Kediri, Indonesia \\ ${ }^{3}$ Institut Agama Islam Negeri Kediri, Indonesia \\ ${ }^{4}$ Institut Agama Islam Negeri Kediri, Indonesia \\ ${ }^{5}$ Universitas Islam Negeri Raden Intan Lampung, Indonesia \\ ${ }^{6}$ Universitas Islam Negeri Sunan Kalijaga Yogyakarta, Indonesia \\ ${ }^{7}$ Universitas Islam Negeri Sunan Ampel Surabaya, Indonesia \\ Correspondent Email: anis.humaidi@gmail.com
}

\begin{abstract}
The process of forming an Islamic boarding school usually has a relationship with social politics. In the Industrial Revolution Era 4.0, there was less and less knowledge about the importance of studying the historical contribution of Islam in Indonesia. The purpose of this research is to analyze the background of the founding of Islamic teachings, movements and social politics in one of the Islamic boarding schools in Indonesia. This study uses the Historical Narrative Study approach. The results found that the Wali Barokah Islamic Boarding School stood behind the founder who tended to be a writer of scriptures and puritans. In addition, the teachings hold fast and, practice the Koran and Hadith, manqul in the transmission of knowledge. The curriculum is summarized in the Al-Manhaj al-Tarbiyah guidelines. On the other hand, the socio-political movement is as follows: Using a more gentle and open method of preaching, as an agent of da'i-da'iyah, in collaboration with outside institutions and with economic activities.
\end{abstract}

Keywords: Social, Politics, Islamic Boarding School of Wali Barokah Kediri

Article Received: 18 October 2020, Revised: 3 November 2020, Accepted: 24 December 2020

\section{Introduction}

The pesantren is etymologically derived from the word santri which gets the prefix and suffix -an so that it becomes a santri that means the word "shastri" which means student. The term pesantren comes from the word shastri which in Indian means someone who knows the holy books of the Hindu religion, or a scholar of the holy books of the Hindu religion. The word shastri comes from the word shastra which means holy books, religious holy books or books about science. Another opinion says, the word santri comes from the word Cantrik (Sanskrit, or maybe Java) which means people who always follow the teacher, which is then developed by Perguruan Taman Siswa in the boarding system called Pawiyatan. The term pondok derives from Arabic fundūq (فندوق) which means lodging. Specifically in Aceh, pesantren are also referred to as dayahs (A'la,
2006).

At first, the pesantren was the oldest Islamic broadcasting education institution in Indonesia (Syahrir et al., 2018). In direct proportion to the dynamics of community life, that function has grown to become richer and more varied, although in essence it cannot be separated from its first function (Maskur, Syazali, \& Utami, 2019). There are so many origins of the establishment of a cottage boarding school (Rifai, 2005). In general, this institution was established because the community recognized the superiority of a cleric in the height of knowledge and wise personality(Syahrir et al., 2019). Then they went to him and studied together to obtain this knowledge. Some people come from the surrounding environment and outside the area. So they built a building near the kyai's house as a 
place to live (Hadi, 1994). According to Mastuhu boarding schools are traditional Islamic educational institutions to understand, live, and practice the teachings of Islam (tafaqquh fi-alddin) by emphasizing the moral importance of the Islamic religion as a guide to everyday life (Abdullah, 1980).

In the opinion of scientists, the term pesantren is two terms that contain one meaning. The Javanese call it "pondok" or "pesantren". Often also referred to as boarding schools. The term "pondok" probably originates from the notion of boarding students called "pondok" or "bamboo" dwellings or perhaps it is derived from Arabic "funduq" meaning a large dormitory provided for stopover. Now better known as pondok pesantren. In West Sumatra, it is known by the name of surau, while in Aceh it is known by the name of the rangkang (Arifin \& Selamet, 2010). Thus, pesantren can no longer be charged solely as a purely religious institution, but also (should) be a living social institution that must continue to respond to the chaotic problems surrounding the community. Actually this has been proven starting from its role in building the Indonesian nation since before independence until this reform era (Arifin \& Selamet, 2010).

Pesantren is the oldest Islamic educational institution which is a product of Indonesian culture. When the pesantren was established, where and by whom no definitive information was obtained (Fuenmayor \& Orozco, 2019). From the data collection of the religious department in 1984-1985 as quoted by Mastuhu, it was obtained that the oldest pesantren was established in 1062 in the name of Jan Tampes II pesantren in Pamekasan Madura. In addition there are other allegations including the existence of Islamic boarding schools in Indonesia starting from Islam entering the country by adopting a religious education system that actually has long developed before the arrival of Islam (Mastuki, 1997). As an educational institution that has long been rooted in this country (De Velazco, Hernández, \& Ripoll, 2019), boarding schools are recognized to have a very large contribution to the history of the Indonesian people (Dananjaya, 1994).

Islamic boarding schools are basically Islamic educational institutions in which all knowledge related to Islam is expected to be obtained at Islamic boarding schools (Lestari et al., 2019). This means that Islamic boarding schools are Islamic educational institutions with distinctive features (Nasir, 2005). According to Nurcholish Madjid, if Indonesia did not experience colonialism (Moesa, 2007), then the growth of the education system in Indonesia would follow the path of the pesantren (H. P. Daulay, 2001). This opinion was made referring to the history of Western education that almost all famous universities (Muhammadiyah, 2013), the forerunner was a religious college. If there was no occupation, the existing tertiary institution would not be Brawijaya University, UGM or ITB, but Tebuireng University, Lasem University, or Krapyak University.

During its development, around 1945 to 1960, pesantren were the most popular educational institutions in the community (Mastuhu., 1994; Rahmawati, Lestari, \& Umam, 2019). This phenomenon is inseparable from the economic situation (Kasayanond, Umam, \& Jermsittiparsert, 2019) and conditions of the Muslim community at that time which was very difficult (Mastuhu, 1999), so that pesantren is an alternative for the poor of Indonesia. But after the crisis of the 60s, pesantren showed another phenomenon (Lexy, 2002; Ramadhani, Umam, Abdurrahman, \& Syazali, 2019), which was not only attractive to the poor but also by rich people (Dhofier, 1985).

In the beginning, the purpose of establishing pesantren was to become an Islamic educational institution that spread information about the teachings of Islam to the public throughout the archipelago which had a pluralist character, both in the dimensions of belief (Balsa, 2019), culture, and social (Dahlan, 1992). In addition to being an 
Islamic educational institution, pesantren was also born to respond to social situations and social conditions that are being faced with the collapse of moral foundations, through offered moral transformation (H. H. P. Daulay, 2018).

In Indonesia there are several typologies of pesantren including: salafiyah (traditional) pesantren, khalaf (modern) pesantren, and integrated pesantren. These pesantren are rooted in Indonesian nuance, very accommodating to the nation's culture, tolerant, inclusive and teach the spirit of nationalism.

\section{Research Methods}

This study uses the historical studies approach, which is an approach to examine past events. Historical events are reproduced using primary data sources in the form of testimonies from historical actors that still exist. In this case the researchers interviewed the founding students of the Walibarokah boarding school that still existed, the teachers and several sources who knew the Wali Barokah boarding school's journey from year to year.

\section{Research Sites}

This article takes an object in one of the Islamic boarding schools, namely Islamic Boarding Schools whose educational orientation leads to the purification of Islamic teachings namely Wali Barokah Islamic Boarding Schools under the auspices of LDII (Indonesian Islamic Da'wah Institute) Kediri. As for the reasons for the selection of the object of this study in the boarding school Wali Barokah Kediri because this cottage is the origin of LDII throughout Indonesia. This boarding school has something unique that is the fervor of its efforts in order to restore the teachings of the Qur'an and Hadith with its unique characteristics. What's more interesting is that this pesantren is not directly affiliated with one of the political parties in Indonesia as most of the huts are under the auspices of NU with PKB and Muhammadiyah with PAN.

\section{Research Findings}

\section{The Establish of Wali Barokah Islamic Boarding School}

There are a number of things that lay behind the establishment of the Wali Barokah Islamic boarding school (Diani, Herliantari, Irwandani, Saregar, \& Umam, 2019). First, the Thought of Nurhasan Ubaidah, he is a founder who tends to be scripturalist and wants to purify Islam (Arif, 2008). Secondly, He was concerned about the people at that time who were far from the Qur'an and Sunnah. From the background of the founder's thought, Nurhasan Ubaidah, it is reasonable to call this Islamic boarding school Islamic boarding school (Wahid, 2010). According to Jainuri Islamist is a group that believes that the Qur'an and Sunnah are the basic and binding sources of Islamic teachings to be implemented everyday (Dirdjosanjoto \& Umat, 1999; Habibi et al., 2019). Islamists have a scripturalist tendency to cling to the main sources of Islam (Rahma Diani et al., 2019; Jaimes, 2019). In this case Geertz explains the "scripturalist" understandings of Islam that emphasize the primacy of religious texts, especially the Qur'an and Hadith (traditions concerning the Prophet Muhammad and his close companions) (Haedari, 2007). Of course this thinking model cannot be separated from the influence of the environment in which Ubaidah is studying (Fatah, Taufik, \& Bisri, 2005). Ubaidah studied in Mecca where religious extremes followed Muhammad ibn Abdul Wahhab. Abd-alWahhab was a scholar who strongly emphasized Muslims returning to the Qur'an and Sunnah (Wekke12 \& Siddin, 2019), he also strongly criticized the practices of worship and traditions before Islam.

\section{Types of Pesantren}

Based on its components, Manfred Ziemek (1986) classifies pesantren typologies into five, namely:

\section{Pesantren Type A}


The simplest boarding school, where the pesantren only consists of a mosque which is used as well as a place for teaching classical books and kyai houses to stay the students. The number of students is usually small and stays at the kyai's house, resulting in a close family relationship. The small number of students makes it easy for kyai and their families to control the activities of students(Harits, 2004).

\section{Pesantren Type B}

It is a type A development, which is a pesantren which consists of a mosque as a place to teach and a place of worship, a kyai house and a cottage which is a dormitory for students who also become manganese to live and a simple place of study.

\section{Pesantren Type C}

It is the development of type B which is added by the expansion of pesantren with the inclusion of classical methods in the form of madrasa that shows the modernization of Islam. Madrasa with a class level provides many lessons that are not religious. The curriculum is oriented towards official government schools. The children who live around 14 boarding schools as well as the students who live in the boarding schools themselves are taught in madrasas as an alternative to government primary schools or even at the same time they visit both (Harits, 2004).

\section{Pesantren Type D}

It is a type $\mathrm{C}$ boarding school development, which has been supplemented by additional skills education programs for students and for adolescents around the pesantren, for example: courses, carpentry, animal husbandry, and others.

\section{Pesantren Type E}

Is the development of type $\mathrm{D}$ pesantren, which is a type of modern boarding school, where Islamic education is implemented in the Classical Method, covering all levels of public schools (formal) starting from elementary school education to tertiary education. The difference regarding the illustration between pesantren A, B, C, D and E can be seen in Figure 1.

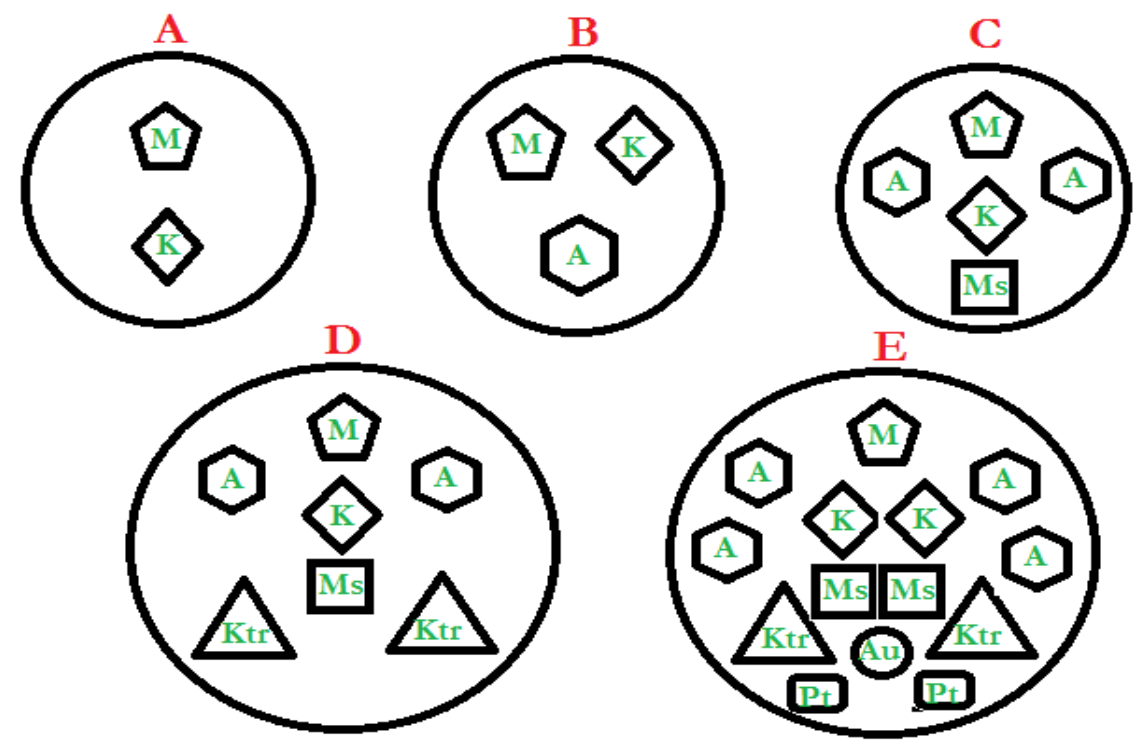

Figure 1. The difference regarding the illustration between pesantren A, B, C, D and E. Information :

$\begin{array}{llrlr}\mathbf{M} & \text { : Masjid } & \text { : Madrasa } & \text { Pt } & \text { : University } \\ \mathbf{K} & \text { : Kyai (teacher) House } & \mathbf{K t r} & \text { : Office } & \\ \mathbf{A} & \text { : Dormitory } & \mathbf{A u} & \text { : Hall } & \end{array}$

Wali Barokah Pesantren in terms of teaching, became an exclusive pesantren because it rejected the traditions that had taken root in Java, whereas the basic character of the pesantren was education 
which had roots in the Javanese tradition. Martin van Bruinneseen said, "The beginnings of Indonesia's pesantren tradition may not go back as far as has often been claimed. Certain scholars have claimed that the pesantren represented a continuation of similar schools with resident students in the pre-Islamic period (Woodward, Amin, Rohmaniyah, \& Lundry, 2013).

According to Nurcholish Madjid, another difference that distinguishes between Ahl alsunnah wa al-jamaah and the others is related to adat issues, especially Javanese customs. The students rejected a lot of Javanese elements, but also retained some of the others later given the color of Islam (Trinova \& Kustati, 2019). Among the examples of adat that are rejected by Islamic boarding schools are nyadran. This tradition still exists among the people of Java today even though they have declared Islam. Almost every village in Java found a tomb that was saved, generally the tomb of the founder of the village. Villagers always ask for safety at the tomb if you want to have a lavatory. The students reject this practice because they assume that the practice of nyadran is shirk because it asks other than Allah.

\section{Developments in Contemporary}

\section{Pesantren: Islamic Boarding Schools}

At first the understanding of Islamist connotes politics or resistance to the status Quo as in the oxford dictionary of Islam. "Term used to describe an Islamic political or social activist. Coined in preference to the more common term "Islamic fundamentalist." Islamists (al-Islamiyyun) are committed to the implementation of their ideological vision of Islam in the state and/or society (Jainuri, 2004). Their position is often seen as a critique of the establishment and status quo (Sagala, Umam, Thahir, Saregar, \& Wardani, 2019; Sriyakul, 2019). Most belong to Islamic organizations or social movements (al-harakat alIslamiyyah).

Islamist activities in politics such as establishing parties, establishing organizations (Streenbrink \&
Madrasah, 1994) and so on. In the field of formal education such as establishing integrated schools (Umam \& Sommanawat, 2019) and in informal education such as making liqa, majelis ta " ${ }^{\text {"lim }}$ and establishing pesantren.

At present the term Islamist is also used to describe pesantren educational institutions. This is an evolution that occurred in the world of pesantren. Islamic boarding schools whose origins are the result of cultural and religious acculturation have become Islamic boarding schools oriented towards purifying Islamic teachings (Mastuhu., 1994). This term is not as popular as other pesantren terms such as salaf or traditional pesantren, modern pesantren but there are many pesantren models that lead to these pesantren Islamists (Laffan, 2003).

The term Islamist to refer to this pesantren was raised by Martin Van Bruinnessen in one of his articles "Traditionalist and Islamist Pesantrens. In Contemporary Indonesia "Martin writes that describing a pesantren which is identical to the purification of Islam. The Islamicology typology of this pesantren is also not easy to generalize and needs to be careful in elaborating because pesantren in this typology have many variants even at the same outline, namely Islamic fundamentalism.

Islamists have a scripturalist tendency, clinging to the main sources of Islam namely the Qur'an and Hadiths. Concept for Islamist movements, is the restoration of the pristine purity of the ummah at the time of Muhammad and his companions. Islamist movements thus draw inspiration from a reading of Islamic sources (Qur'ān and sunnah) with the aim of remodeling contemporary Muslim majority societies according to scriptural norms. They envisage a virtuous political community based on the observance of the shar'ah - a purified ummah to be built up through proselytizing activities (proselytizing), charitable practices, and principled policies. Geertz (1971) explains the "scripturalist" understandings of Islam that 
emphasize the primacy of religious texts, especially the Qur'an and Hadith (traditions concerning the Prophet Muhammad and his close companions).

Islamists emphasize their movement as a purification movement towards the teachings of Islam and sharia oriented. Hospitality towards local culture is a common feature of Islamist movements based on fundamentalist teaching. Negative evaluations of cultural practice are based on the assumption that Shari'ah and Sunnah (the social practice of the Prophet Muhammad) are the only acceptable models for Muslim conduct.

Islamists believe that shari'ah is governing all human life. Islamists "have come into increasing use in recent years to denote the views of those Muslims who claim that Islam, or more specifically, the Islamic sharī'ah, provides guidance for all areas of human life, individual and social, and who therefore calls for an" Islamic State "or an" Islamic Order. "Islamists focus primarily on political matters, but they are also concerned with economic, social, and moral issues. Because of that the main struggle of Islamists is to establish Islamic shari'ah. The Islamists' claim that they are divinely-ordained and immutable, valid for all times and places.

\section{Wali Barokah Kediri Islamic Boarding School Social and Political MovementWali Barokah}

Islamic Boarding School social movements are as follows:

1) Wali Barokah Islamic Boarding School uses propaganda method more softly and openly unlike Islamic preaching of Jemaah and Lemkari. This method of preaching was carried out after the Ubaidah teachings were repeatedly pressured by the community, so the strategy for LDII teachings to be more acceptable to the community, then LDII need to change the method of propaganda with more soft. Organizations that are now LDII from time to time always take lessons so that preaching can be accepted in the community. When changing from Islam Jamaat to Lemakari has a motto that Lemkari shows a more tolerant attitude that respects the beliefs of others. Lemkari brought a new spirit, preaching without violence or without blaspheming other parties who are often accused of KH. Nurhasan and his students. This attitude reinforces that this new organization (Lemkari) is a nationalist Islamic organization that supports Pancasila and the 1945 Constitution. Including the change from the name Lemkari to LDII in 1990 is also an effort to proselytize more softly.

This is one phenomenon that is quite unique that Islamists in general often use violent methods in their da'wah. But the Wali Barokah pondok rapidren turned soft.

1) Wali Barokah boarding school is a militant da'i-da'iyah agent who is ready to be placed anywhere.

2) The practice of preaching to the community is carried out by preaching bil p. After the community is interested in the LDII people's behavior the community will follow it.

3) By working with institutions outside of other organizations such as with NU, Muhammadiyah.

4) Another form of LDII socialization is the economic activity, LDII has several business entities, with its business as well as a means of preaching, so that many business relations are interested in entering LDII.The Wali Barokah Islamic Boarding School political movement is as follows:

2) In politics, LDII considers that Indonesia is a final country. Islamic Sharia does not need to be used as the basis of the Indonesian State. Actually there is a boarding school guardian barokah in particular and LDII generally have similarities with other religious movements when they have to return to the Qur'an and hadiths (Kholid \& Supriyadi, 2019). However, what distinguishes between LDII or other Islamists is that LDII does not want to make Islam the basis of the state. In contrast to Hizb ut-Tahrir, for example, Hizb ut-Tahrir has the ideals of 
upholding Islamic sharia as the law and the basis of the state and its ending wants to uphold the Khilafah Islamiyah. The function of the Imamate or Imamate in LDII is only as an effort to improve the course of an organization not for political purposes. In the political field, LDII considers that Indonesia is a final country. Islamic Sharia does not need to be used as the basis of the Indonesian State. This is something that is different from other Islamists and interesting to study, in general Islamists believe that the Islamic state and Islamic shari'ah are the most appropriate solution to overcome all the problems of the people. Among Islamist political and religious organizations in Indonesia who hold such views are PKS and HTI. Therefore they are fighting for the establishment of Islamic shari'ah and believe that in a short time the Islamic shari'ah will be established in Indonesia. Claiming that Islam's hold 'over the minds and hearts of believers' transcends all social, economic, class, gender, and demographic demarcations among Muslims, Gellner asserted that if' Christianity has its Bible belt, 'Islam, in its entirety,' is a Qur'an belt'.

3) But Wali Barokah Islamic boarding schools in particular and LDII in general do not make the establishment of an Islamic state and the establishment of Islamic Shari'ah in Indonesia a goal in its struggle. From this it appears that the Wali Barokah Islamic boarding school is different from other Islamists. When analyzed, this is a strange phenomenon, the teachings of the Wali Barokah Islamic boarding school whose memorandum tends to the scriptural understanding but does not call for establishing an Islamic government and establishing shari'ah, in the case of many verses of the Koran which if understood textually it will lead there.

This finally raises a big question why is that? It could be that this is a historical trauma, if LDII or Wali Barokah Islamic boarding school does this it will repeat the dark history that will be opposed by many groups or will be dissolved by the government (Freites \& Trejo, 2019). Or it could be the Wali Barokah boarding school waiting until the right time to voice the establishment of the Shari'ah Islamiyyah and the establishment of an Islamic state (Palacios, Morillo, \& González, 2019). The third possibility is the Wali Barokah Islamic boarding school realizing that Indonesia which is based on Pancasila and the 1945 Constitution is a state that is final so it is not appropriate to voice an Islamic state. This last possibility has been conveyed by the boarding boarder of Wali Barokah boarding school to researchers.

Regarding security it is worth analyzing too, the term Amir is identical to the Islamic leader, when the Messenger of Allah had died the leader of the Islamic government was in the hands of $\mathrm{Abu}$ Bakr, He was called amiril mu'minin, thus the second caliph Umar bin Khattab also got the same title (Laffan, 2003). LDII or Wali Barokah boarding school also uses the term in carrying out its teachings. Will this lead to an organization that leads to the establishment of an Islamic state? But when researchers try to probe deeper, while still getting an answer that the function of the priesthood or Imamat in LDII or Wali Barokah Islamic boarding school is only an effort to improve the course of an organization (Jamil, 2005).

Since the start of the establishment of Islamic Jama'ah until the reform period berailansi with one political party, namely Golkar, but after the fall of the new order, LDII as a form of Islam Jamaah gave freedom to its members to choose parties, so LDII members can choose whatever party they want. The joining of Islam Jama'ah or Lemkari to Golkar is that there is an interest and mutual benefit. On one side, Lemkari's entry into Golkar was able to get a lot of votes from Islamic groups. The advantage for Lemkari is getting a fortress from the government or Golkar. However, this actually sparked extraordinary resentment from Islamic groups and finally urged to dissolve the Islamic Jamaat. This Islamist is indeed 
different from other Islamist groups, usually other Islamists in fighting for their strong political aspirations for their founding based on the Qur'an and Hadith. However, LDII in politics can work with political parties that can benefit both groups from the Islamic group or not. LDII also does not establish relations with foreign countries except for the study of students. Usually the Islamist movement always has an international network with other countries, especially Middle Eastern countries like Hizb ut-Tahrir.

\section{Conclusion}

The emergence of Islamist boarding school (boarding house wali Barokah) was motivated by Nurhasan Ubaidah's concern about the religious practices of the people who according to him followed the tradition and had deviated from the Qur'an and Sunnah. This view of Ubaidah is inseparable from his educational background in the city of Makkah, Saudi Arabia, which tends to follow the ideas of Sheikh Muhammad ibn Abdul Wahhab. Nurhasan Ubaidah felt called to return his community to the right path, namely returning to the Qur'an and Sunnah, he gathered a number of people then taught and doctrine and finally was born Wali Barokah boarding school and LDII now.

The contents of the teachings of Islamic boarding schools (Pondok Pesantren Wali Barokah) return to al-Qur'an and Sunnah so that the material taught is not separated from the Qur'an and Sunnah by way of manqul from Nurhasan Baidah. To get the maximum results in delivering the teachings, there are several doctrines that each student must obey. While the curriculum used is different from the curriculum in Islamic boarding schools in general that makes the work of medieval scholars or the yellow book as objects of study.

The social movement is carried out by Islamic boarding schools (Pondok Pesantren Wali Barokah) by recruiting students to be educated and fostered and then assigned to spread the teachings of the Wali Barokah boarding school to all corners of the world starting from the closest family, neighbors, friends and people around him . In addition, the economic empowerment and social assistance provided to the surrounding community. As for the political arena, the boarding house of the Wali Barokah boarding school is currently not affiliated with any of the domestic parties or foreign policy. Wali Barokah boarding school supports NKRI based on Pancasila and the 1945 Constitution. Thus Wali Barokah boarding school in particular and LDII can generally be classified as non-radical Islamists in politics.

\section{REFERENCES}

[1] A'la, A. (2006). Pembaruan pesantren: PT LKiS Pelangi Aksara.

[2] Abdullah, H. (1980). Perkembangan Ilmu Tasawuf dan Tokoh-tokohnya di Nusantara. Surabaya: Al Ikhlas, tt. 203 pages.

[3] Arif, M. (2008). Pendidikan Islam Transformatif: LKIS Pelangi Aksara.

[4] Arifin, I., \& Selamet, M. (2010). Kepemimpinan Kiyai Dalam Perubahan Menejemen Pondok Pesantren: Kasus Ponpes Tebu Ireng. Pustaka Pelajar.

[5] Balsa, J. (2019). La metáfora del "escenario" en la dinámica política y la valoración de la república parlamentaria en La lucha de clases en Francia y en El Dieciocho Brumario de Luis Bonaparte de Karl Marx. Utopía y Praxis Latinoamericana, 24(2), 220-238.

[6] Dahlan, A. A. (1992). Pembelaan Terhadap Wahdat al-Wujud: Tasawuf Syamsuddin Sumatrani. Ulumul Qur'an, 3(8), 98-113.

[7] Dananjaya, J. (1994). Antropologi psikologi: teori, metode dan sejarah perkembangannya: RajaGrafindo Persada.

[8] Daulay, H. H. P. (2018). Sejarah Pertumbuhan \& Pembaruan Pendidikan Islam di Indonesia: Kencana. 
[9] Daulay, H. P. (2001). Historisitas dan eksistensi: Pesantren sekolah dan madrasah: Tiara Wacana Yogya.

[10] De Velazco, J. J. H. G., Hernández, A. C. C., \& Ripoll, R. R. (2019). Mirada transdisciplinaria de la participación ciudadana y la felicidad social en el discurrir del milenio. Revista Utopia y Praxis Latinoamericana, 24(3), 46-59.

[11] Dhofier, Z. (1985). .Tradisi Pesantren Studi Tentang Pandangan Hidup Kyai. Jakarta: LP3ES.

[12] Diani, R., Herliantari, H., Irwandani, I., Saregar, A., \& Umam, R. (2019). The Effectiviness of SSCS Learning Model: Its Impact on the Students' Creative ProblemSolving Ability on the Concept of Substance Pressure. Jurnal Penelitian Fisika Dan Aplikasinya (JPFA), 9(1), 6577.

https://doi.org/http://dx.doi.org/10.26740/j pfa.v9n1.p\%25p

[13] Diani, R., Irwandani, I., Al-Hijrah, A.-H., Yetri, Y., Fujiani, D., Hartati, N. S., \& Umam, R. (2019). Physics Learning through Active Learning Based Interactive Conceptual Instructions (ALBICI) to Improve Critical Thinking Ability. Jurnal Penelitian Dan Pembelajaran IPA, 5(1), 48-58.

https://doi.org/10.30870/jppi.v5i1.3469

[14] Dirdjosanjoto, P., \& Umat, M. (1999). Kyai Pesantren dan Kyai Langgar di Jawa. Yogyakarta: LKiS.

[15] Fatah, R. A., Taufik, M. T., \& Bisri, A. M. (2005). Rekonstruksi pesantren masa depan: dari tradisional, modern, hingga post modern: Listafariska Putra.

[16] Freites, Z. M., \& Trejo, G. Z. (2019). Redes sociales como canales de digiimpacto en la participacion ciudadana/Social Networks as Digi-Impact Channels in Citizen Participation. Utopía y Praxis Latinoamericana, 24(S3), 30-46.

[17] Fuenmayor, R. C., \& Orozco, G. L.
(2019). Tension entre democracia y autoritarismo en Latinoamerica y el rol del poder judicial/Conflict between Democracy and Authoritarianism in Latin America: The Role of the Judiciary. Utopía y Praxis Latinoamericana, 24(S3), 75-101.

[18] Habibi, B., Hartinah, S., Umam, R., Syazali, M., Lestari, F., Abdurrahman, A., \& Jauhariyah, D. (2019). Factor Determinants of Teacher Professionalism as Development of Student Learning Education at School of SMK PGRI in Tegal City, Indonesia. Journal of Gifted Education and Creativity, 6(2), 123-132.

[19] Hadi, A. W. M. (1994). "Syeikh Hamzah Fansuri” dalam Jurnal Ulumul Qur'an, No. IV Vol. V., tahun.

[20] Haedari, A. (2007). Transformasi pesantren. Jakarta: Media Nusantara.

[21] Harits, A. B. (2004). Ilmu Laduni dalam Perspektif Teori Belajar Modern. Yogyakarta: Pustaka Pelajar.

[22] Ismail Suardi Wekke, Siddin Siddin, Sukree Langputeh. 2019. Islamic Education in Thailand Pattani Muslim Minority: What are the Institutional Continuity and Change? Tadris: Jurnal Keguruan dan Ilmu Tarbiyah. pp 127-134. 10.24042/tadris.v4i1.3753

DOI: 10.24042/tadris.v4i1.3753

[23] Jaimes, E. C. (2019). Democracia y administracion publica en Venezuela/Democracy and Public Administration in Venezuela. Utopía y Praxis Latinoamericana, 24(S3), 10-30.

[24] Jainuri, A. (2004). Orientasi ideologi gerakan Islam: konservatisme, fundamentalisme, sekularisme, dan modernisme: Lembaga Pengkajian Agama dan Masyarakat.

[25] Jamil, M. M. (2005). Tarekat dan dinamika sosial politik: tafsir sosial sufi Nusantara: Pustaka Pelajar.

[26] Kasayanond, A., Umam, R., \& Jermsittiparsert, K. (2019). Environmental 
sustainability and its growth in Malaysia by elaborating the green economy and environmental efficiency. International Journal of Energy Economics and Policy, 9(5), 465. https://doi.org/https://doi.org/10.32479/ijee p. 8310

[27] Kholid, I., \& Supriyadi, S. (2019). Students Instrumental Motivation: An Investigating toward English Learning of Students in Islamic Higher Education. Tadris: Jurnal Keguruan dan Ilmu Tarbiyah, 4(1), 51-62.

[28] Laffan, M. (2003). The tangled roots of Islamist activism in southeast asia. Cambridge Review of International Affairs, 16(3), 397-414. 10.1080/0955757032000132335.

[29] Lestari, F., Saryantono, B., Syazali, M., Saregar, A., Madiyo, M., Jauhariyah, D., \& Rofiqul, U. (2019). Cooperative Learning Application with the Method of" Network Tree Concept Map": Based on Japanese Learning System Approach. Journal for the Education of Gifted Young Scientists, $\quad 7(1), \quad 15-32$. https://doi.org/10.17478/jegys.471466

[30] Lexy, J. M. (2002). Metodologi penelitian kualitatif. Bandung: Remaja Rosdakarya. Maskur, R., Syazali, M., \& Utami, L. (2019). Islamic-Nuanced Calculus Module with Open-Ended Approach in Real Number System Material. Paper presented at the Journal of Physics: Conference Series. https://doi.org/10.1088/17426596/1155/1/012081.

[31] Mastuhu, M. (1999). Memberdayakan Sistim Pendidikan Islam. Cet. II, Jakarta: Logos Wacana Ilmu.

[32] Mastuhu. (1994). Dinamika Sistem Pendidikan Pondok Pesantren. Jakarta: INIS,

[33] Mastuki, H. (1997). Neosufisme di Nusantara. Ulumul Qur'an, VII(6).

[34] Moesa, A. M. (2007). Nasionalisme Kiai;
Konstruksi Sosial Berbasis Agama: LKIS PELANGI AKSARA.

[35] Muhammadiyah, H. (2013). LDII: pasang surut relasi agama dan negara: Elsas.

[36] Nasir, M. R. (2005). Mencari Tipologi Format Pendidikan Ideal: Pondok Pesantren di Tengah Arus Perubahan: Pustaka Pelajar.

[37] Palacios, A. N., Morillo, J. P., \& González, A. I. (2019). Educacion en y para la democracia/Education on Democracy. Utopía y Praxis Latinoamericana, 24(S3), 60-75.

[38] Rahmawati, R., Lestari, F., \& Umam, R. (2019). Analysis of the Effectiveness of Learning in the Use of Learning Modules Against Student Learning Outcomes. Desimal: Jurnal Matematika, 2(3), 233240.

[39] Ramadhani, R., Umam, R., Abdurrahman, A., \& Syazali, M. (2019). The effect of flipped-problem based learning model integrated with LMS-google classroom for senior high school students. Journal for the Education of Gifted Young Scientists, $7(2)$,

137-158. https://doi.org/https://doi.org/10.17478/jeg ys. 548350

[40] Rifai, R. (2005). Dakwah tuan guru Kiai H. Muhammad Zainuddin Abdul Majid dalam rangka pembaruan Islam di Lombok, NTB: laporan penelitian: Fakultas Keguruan dan Ilmu Pendidikan, Universitas Mataram.

[41] Sagala, R., Umam, R., Thahir, A., Saregar, A., \& Wardani, I. (2019). The Effectiveness of STEM-Based on Gender Differences: The Impact of Physics Concept Understanding. European Journal of Educational Research, 8(3), 753-761. https://doi.org/http://doi.org/10.12973/eujer.8.3.753

[42] Sriyakul, T., Umam, R., Jermsittiparsert, K., Development, T., Chi, H., City, M., ... City, M. . (2019). Internal Supply Chain Integration And Operational Performance 
Of Indonesian Fashion Industry Firms : A Supplier to Buyer Approach. Humanities \& Social Sciences Reviews, 7(2), 479486.

https://doi.org/10.18510/hssr.2019.7256.

[43] Streenbrink, K. A. P., \& Madrasah, S. (1994). Pendidikan Islam dalam Kurun Moderen. Jakarta: LP3ES.

[44] Syahrir, S., Syazali, M., Maskur, R., Amrulloh, M., Sada, H., \& Listiani, B. (2019). Calculus Module for Derivative Application Materials with an Islamic Contextual Teaching and Learning Approach. Paper presented at the Journal of Physics: Conference Series. https://doi.org/10.1088/17426596/1155/1/012079.

[45] Trinova, Z., \& Kustati, M. (2019). Lecturers' Professionalism: Reflective Experiences among Islamic State Universities in West Sumatera. Tadris: Jurnal Keguruan dan Ilmu Tarbiyah, 4(1), 63-75.

[46] Umam, R., \& Sommanawat, K. (2019). Strategic flexibility, manufacturing flexibility, and firm performance under the presence of an agile supply chain: A case of strategic management in fashion industry. Polish Journal of Management Studies, 19. https://doi.org/10.17512/pjms.2019.19.2.3 5

[47] Wahid, A. (2010). Menggerakkan Tradisi.Yogyakarta: PT. LKiS Printing Cemerlang.

[48] Wekke12, I. S., \& Siddin, S. L. (2019). Islamic Education in Thailand Pattani Muslim Minority: What are the Institutional Continuity and Change? Tadris: Jurnal Keguruan dan Ilmu Tarbiyah, 4(1), 127-134.

[49] Woodward, M., Amin, A., Rohmaniyah, I., \& Lundry, C. (2013). Getting culture: a new path for Indonesia's Islamist Justice and Prosperity party? Contemporary Islam,
7(2), 173-189.

[50] Zulvia Trinova, Martin Kustati. 2019. Lecturers' Professionalism: Reflective Experiences among Islamic State Universities in West Sumatera. Tadris: Jurnal Keguruan dan Ilmu Tarbiyah.. pp 63-75. 10.24042/tadris.v4i1.4117 